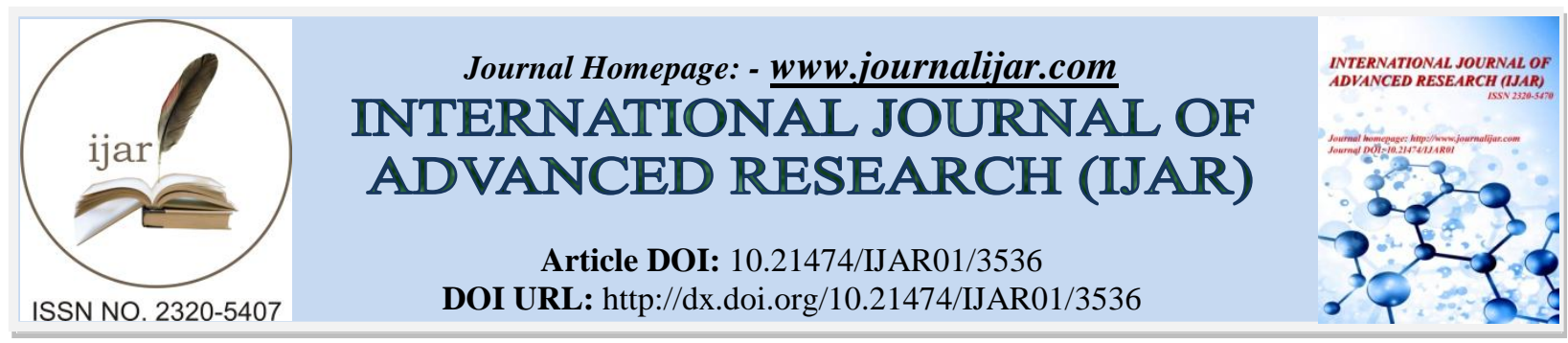

RESEARCH ARTICLE

\title{
QUALITY OF HEALTH SERVICE AND ITS EFFECT ON PATIENT SATISFACTION IN DR. SYAIFUL ANWAR HOSPITAL OF MALANG INDONESIA.
}

\begin{abstract}
Suyitno.
Indonesia Economic College, Jl. Mega Mendung 1-9 Malang, Indonesia.

\section{Manuscript Info}

Manuscript History

Received: 12 January 2017

Final Accepted: 14 February 2017

Published: March 2017

Key words:-

service quality, patient satisfaction, public hospital, Dr. Syaiful Anwar

Hospital.

\section{Abstract}

Service quality dimension covering reliability, responsiveness, assurance, empathy, and tangible is the ultimate goal a public hospital should achieve as organization productivity though patients' satisfaction. This study investigated the influence of service quality on patients' satisfaction of Dr Syaiful Anwar Hospital in Malang, East Java, Indonesia. Assigning 50 patients hospitalized during the research, this study collected data using questionnaires, interview and document analysis and used SPSS 17.0 as a tool of analysis. Findings of t-test showed that variables of quality service gave positive effect on patients' satisfaction, each of which is: Assurance (46\%), Reliability (34,3\%), Tangible (42\%), Responsiveness $(67,1 \%)$, and Empathy $(43,3 \%)$. Determinant test showed all variables affected $46.1 \%\left(\mathrm{R}^{2}=\right.$ .464) on public satisfaction and responsiveness performed the most dominant effect on patients' satisfaction to $67.1 \%$ based on beta test.
\end{abstract}

Copy Right, IJAR, 2017,. All rights reserved.

\section{Introduction:-}

Satisfaction is feeling happy or disappointed someone has after comparing a perception or impression of the performance of a product and expectations. Satisfaction is a function of perception or impression of performance and expectations (Kotler, 2002). The quality of health care services to patients can not be separated from the employee's role as a provider of services to patients. Management commitment to quality of service is the first step process of providing excellent service to patients. Likewise, employees' commitment to the quality of service is standard, it is the continuous effort of the employee to provide service beyond the minimum standards set. Employee satisfaction to their job will be a positive influence on the quality of services received by users.

The fast development of human resource management that regarded nurses or clerks as a burden or cost, is currently changing the value to asset health. Therefore, almost all large and small health institutions will make every effort to develop human resources as much as possible through improving the quality and performance of the nurses to provide job satisfaction for employees.In conditions of fierce competition, each hospital attracts and retains patients, as well to apply right strategy to achieve patient's satisfaction. This means that no matter how small the patient's complaint, the hospital must respond positively, because the handling of complaints could provide an opportunity to turn disgruntled customer into a satisfied customer or even become immortal customer (Schnaars, 1991). According Artanti (2015), the impacts of dissatisfied customers vary: 90\% of dissatisfied customers will not return to the hospital; a customer that is unsatisfied will tell at least to 9 other friends or relatives; a customer that is satisfied with the services will tell to others and direct them into customers; $13 \%$ of customers who were disappointed will tell to 
more than 20 people; the cost to recruit new customers requires five times higher than if we maintain relationships with existing customers.

Dr. Saiful Anwar Public Hospital Malang is one of the spearheads of local government providing public health service. Management makes improvements for the sake of reform, particularly to improve service quality through evaluating the standard of service and formulation of policy services. By doing so, the hospital can make improvements on service quality and give satisfaction to public users, especially the patients.

To determine the patient's perception of service quality and satisfaction an empirical study is required. Evaluations carried out in general are not enough for management of the hospital, because the information can not be generated for all patients in the hospital. For the sake of the future strategic decisions, only research activities are appropriate to provide answers.

The main problem of the hospital as an institution of health services that challenges many competitors is whether its service has been devoted according to the expectations of patients or not? As local hospital, Dr. Saiful Anwar Hospital should always maintain confidence and satisfaction of patients as customers through improving quality of its services to increase patient satisfaction. Dr. Saiful Anwar Hospital needs to determine carefully the needs of patients as an effort to meet the desires and improve satisfaction services provided. Building relationships and conduct a study of patients are required to adjust services as expected. This is the concept of customer focus. The creation of quality of service will surely create user satisfaction with the service. The implication would be able to provide many benefits, including establishment of a harmonious relationship between providers of goods and services to customers, provide a good foundation for the creation of customer loyalty and make the patient as an agent of promotion.

The hospital has a system of health care standards set by the government, that is a standard service-oriented to customer satisfaction and a comprehensive standard for enterprise services. One effort of the hospital to win the competition is to improve the quality of products or its services. Therefore, hospitals are trying to win competition by improving the quality of products and services, so as to provide customer satisfaction.

In the future, ahospital should have a goal of achieving ISO certification. ISO provides advantages, such as: a better reputation, level of awareness of need to maintain quality, apparent procedures and responsibilities, better documented, eliminating unnecessary work, easier to track and audit, better service to customers, improved customer satisfaction and employee, performing continuous improvement, increasing profits, opportunities for expansion and change the bad image of society to government health services better. Accordingly, implementation of quality management system (ISO 9001:2000) makes service better, all activities are carried out procedurally, documented and regularly and an analysis of previous activities is possibly conducted.

The first step is to know what quality dimensions that influences patient satisfaction, especially patients in the hospital. According to Zeithaml, Berry and Parasuraman (2012) dimensions of quality include: reliability, responsiveness, assurance, empathy, and tangible (real) to qualify customers' satisfaction. Appropriate service policies of patient care should be examined through dimensions of quality services of hospital patients. The problem is whether there is an effect of the quality dimension variables. Thus, orientation of this study is to prove whether there is influence quality of service to client satisfaction based on the dimensions of reliability, responsiveness, assurance, empathy, and tangible at the hospital, to identify dimensions of service quality that gives the most influence on patient satisfaction.

Another problem is how much the influence of dimensions of service quality that consists of reliability, responsiveness, assurance, empathy and tangible to the satisfaction of patients. This study was done to contribute ideas to the management of health care providers to improve services to patients and to give consideration in decision making about the relationship improved service performance at the hospital. The so complex problems of life today that cause health problems makes health care is really critical.

\section{Research Problems:-}

The formulation of the problem of this research are:

a. How are descriptions of quality activities of health service and patient satisfaction in the hospital of Dr Saiful Anwar Malang? 
b. How does dimension quality of health services that include reliability, responsiveness, assurance, empathy, tangible affect partially level of patient satisfaction in the hospital of Dr Saiful Anwar Malang?

c. How does dimension quality of health services that include reliability, responsiveness, assurance, empathy, tangible affect simultanously patient satisfaction in the hospital of Dr Saiful Anwar Malangd.

d. What is dimension quality that affect the dominant influence on patient satisfaction of Dr Saiful Anwar Hospital in Malang?

\section{Review of Literature:- \\ Quality:-}

Quality is a zero defect, completeness and conformance to requirements. Quality is conformance to specifications, when viewed from perspective of manufacturer. Juran, (in Yamit, 2005:337) defines quality as a standard specifically where the ability (availability), performance, reliability, ease of maintenance (maintainability) and its characteristics can be measured. Davis, (in Yamit, 2005:8) makes the definition of quality broader in scope, as a dynamic condition related to products, services, people, processes, and environments that meet or exceed expectations. The approach used by Davis asserts that quality is not only emphasized on aspect of final result, i.e. products and services but also human quality, and quality of the environment. It is impossible to produce qualified products and services without qualified people and processes.

To provide product services is in contrast to produce manufactured products in some ways. Such differences have important implications in quality management. Zeithaml, Berry and Parasuraman, (in Yamit, 2005:10-12) has conducted various studies on types of services, and managed to identify five dimension characteristics used by customers in evaluating quality of service.

\section{The fifth dimension of service quality characteristics are:}

a. Reliability, the ability to provide services quickly and satisfactorily and in accordance with what is already promised.

b. Responsiveness (comprehension), desire of the staff to help customers and provide service with a full response.

c. Assurance (collateral), the ability, courtesy and trustworthiness owned by the staff, free from danger, risk or hesitations.

d. Empathy, ease in the relationship, good communication, and attention sincerely to customers' needs.

e. Tangibles (direct evidence), physical facilities, equipment, employees, and means of communication.

Quality of services is strongly influenced by consumer expectations. Consumer expectations can vary from one consumer to another consumer even though the service provided is consistent. The quality may be seen as a disadvantage if consumers' expectations are too high, even good services have been served. According Wyckof in Lovelock (quoted from Purnama, 2006:19-20) notion of service quality is perfection level to meet wishes of consumers. Quality of service is a comparison between perceived service (perception) of consumers with quality of service the customers expect. If the perceived service quality is equal or exceeds from the quality of service being expected, the service is qualified and satisfactory. According to Grönroos (in Purnama, 2006:20) quality of service includes:

a. Quality function, how service is implemented including dimension of contact with consumers, attitudes and behavior, internal relationships, appearance, ease of access, and service mindedness.

b. Technical quality and output quality perceived by costumers, that is price, punctuality, speed of service, and aesthetic output.

c. Company's reputation, reflected by the company's image and reputation in the eyes of consumers.

In sum, quality of service is level of service of excellence to meet the desires of consumers or custumers by an organization. Quality of service is measured by five indicators of service: reliability, responsiveness, assurance, empathy, and tangibles.

\section{Customer Satisfaction:-}

To define actual patient satisfaction is not easy, because the patient has a wide range of characteristics: good knowledge, social strata, experience, income and expectations. For example, a patient coming just wants to try certain health services from a health center. Before transaction, this new patient must have had hopes that he would be better served, waiters are friendly, responsive, and he will be served with therapeutic treatment. If his expectations is consistent with what is experienced and perceived,it exceeds from his expectations and certainly he 
will feel satisfied.Conversely, if he experienced and felt the service is beyond the expectations; for example, the service is unfriendly, unresponsive and ineffective treatment, it is ascertained the patient is not satisfied.

The example above shows patient satisfaction can be seen after the use of products and services. A patient satisfaction is an after-purchase evaluation or evaluation results after comparing what is felt to his expectations. Patient satisfaction is the result (outcome) perceived on the use of products health services, that is equal or exceeds from the expectations (in Zulian Yamit, 2005:78). Patient satisfaction has become a central concept in the management discourse (Tjiptono and Chandra, 2005:192). Public Health Service patients generally expects the health care services enjoyed with good service or satisfactory (Assauri, 2003). Patient satisfaction can shape perceptions and further enhance positioning sub-district health services in the public eye.

Patient satisfaction is the result of perceived control over the use of products and services, equal or exceed the desired expectations. Kotler (2003) suggests several methods to measure patient satisfaction, as follows:

a. The complaint system. This system provides the opportunity for patients to give suggestions, complaints and other forms of dissatisfaction by providing a suggestion box. Any suggestions and complaints entry should be a concern of management, for suggestions and complaints are generally guided by experiences of patients to reflect their love to the an organization.

b. Survey of patients. Survey of patients is a common method used in measuring patient satisfaction, for example, by postal mail, telephone or direct interviews.

c. Panel patients. Management invites loyal patients and patients who have moved to other hospital. The faithfull patients will provide information on the level of satisfaction they feel and the former patients will inform why they move to other hopsital. If patients who are not faithful (customer loss rate) is increasing, this indicates a failure in satisfying the patient's management.

Parasuraman (1998) identifies five dimensions of service quality (Servqual) as follows: (1) Tangible, appearance of physical facilities, including equipment, personnel and means of communication. Tangible could include elements of physical, personnel equipment, and communications materials. The aim is to strengthen quality, comfort, and safety of services offered to consumers. (2) Reliability, company's ability to keep and fulfill the promises given to consumer confidence. According Yasid (1999:113) reliability is the ability of a reliable, accurate and consistent in providing appropriate services that consumers want. (3) Responsiveness, quick response in reading and serve the desires or needs of consumers. The response is the willingness to help customers and provide services immediately. Some organizations choose to focus on the response position. They give attention to the desire of consumers to show "willingness to help" and serve the desires as soon as possible. (4) Assurance, knowledge, reliability, courteous of employees, trustworthy and confident. These dimensions can be used for the positioning by a number of industry effectively, especially if the reliability and confidence of service providers is very important. (5) Empathy, giving genuine concern and a private individual given to consumers by trying to understand the desires of consumers. A company is expected to have knowledge and understanding of consumers, understanding the needs of consumer needs specifically.

Consumers' attitude is actions by individuals, group or organization pertaining to the decision making process to achieve and use goods or services that are affected by the environment including decision making process. One of the fundamental factors on the study of consumers' attitude is people often buy products not for what they do, but for what they mean. This way, consumers buy a product nit to achieve its functions, but for its cetain purposes, e.g. image, pride, and personality. Smart marketers tend to create certain relation between offered product and consumers.

Mowday, et. al., (1979:230) and Roberts (2003:48) developed a model of service quality in the organization connecting factors that affect quality of service to organization. The model compares quality of service in organization with output or consequence of quality of service to the organization, including: personal characteristics (e.g. age and tenure), characteristics of role and work (e.g. identity and feedback), structural characteristics (e.g. formalization and decentralization) and work experience (including cohesiveness group) that will produce output and consequent quality of services organizations in the form of a will to survive in the organization, level of attendance, a feeling of belonging and being part of the organization and a willingness to try as much as possible for the organization. 
Customer satisfaction is determined by the quality of customer services desired, so quality assurance is a top priority for every hospital, which is currently used as a measure of competitive advantage of the hospital. According to Oliver and Doner cited by Kotler et al. (2003) customer expectation is a trust before trying (pre-trial belief) about a product that is used as a standard to evaluate performance of a future product or experience. Based on the description above, the conceptual framework of this study as follows:

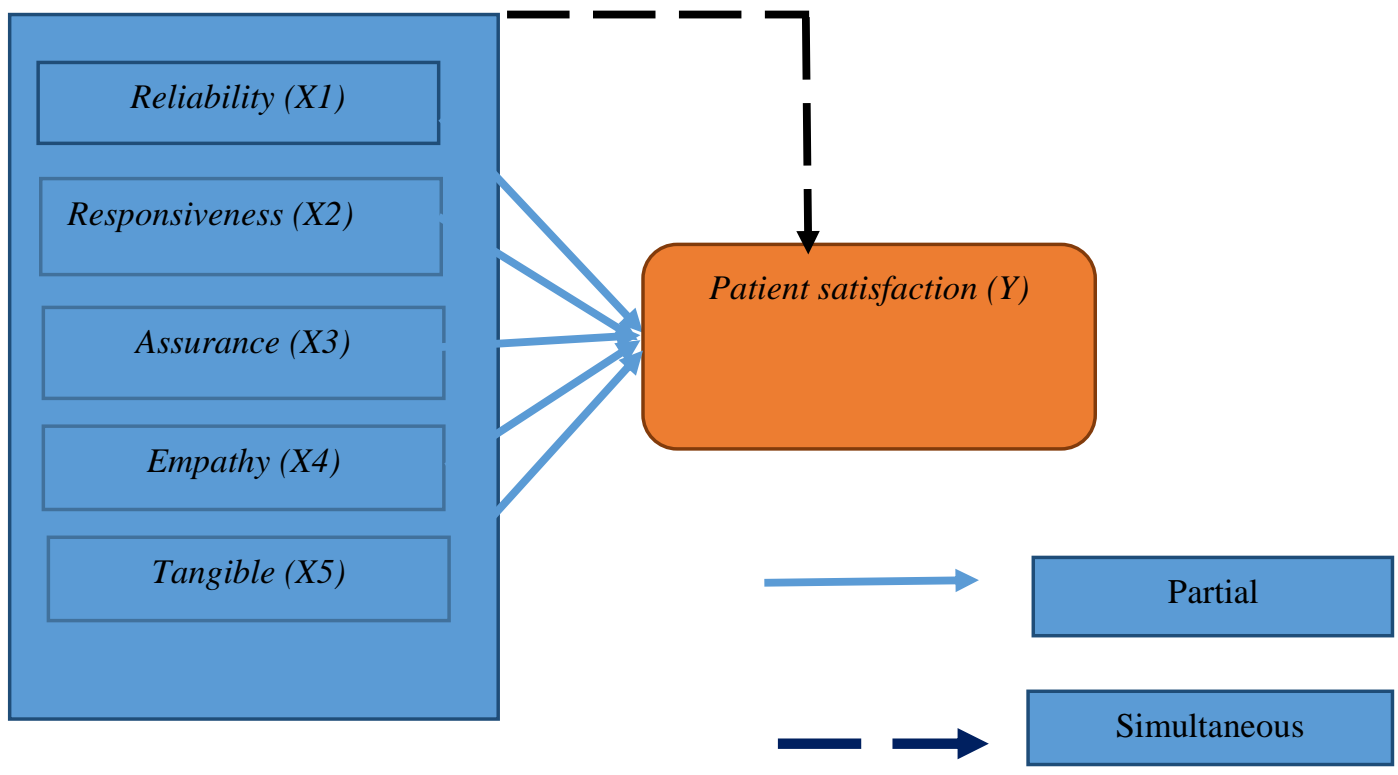

Figure 1:- Conceptual Framework of this Research

\section{Method:-}

This research employed quantitative design with explanatory non-experimental approach. The dependent variables included: reliability, responsiveness, assurance, empathy and tangible; and the independent variable was patient satisfaction. It described the influence of variables of service quality to client satisfaction through hypothesis testing without providing treatment. This study was conducted at Dr. Saiful Anwar Hospital in Malang, Indonesia from April to July 2016, which involved 50 patients as sample. Data were collected using questionnaires, observations and interviews, and were analyzed through descriptive and inferential statistics with SPSS version 17.

\section{Results and Discussion:-}

\section{Regression Analysis:-}

Test of multiple linear regression analysis is to examine and analyze the influence of Reliability, Responsiveness, Assurance, Empathy and Tangible to the satisfaction of the patients of Dr. Saiful Anwar Hospital in Malang. The magnitude of these effects can be seen from the recapitulation of regression testing in table 1.

Table 1:- Result of Regression Analysis

\begin{tabular}{|c|c|c|c|c|c|c|}
\hline \multirow[t]{2}{*}{ Model } & \multicolumn{2}{|c|}{$\begin{array}{l}\text { Un-standardized } \\
\text { Coefficients }\end{array}$} & $\begin{array}{l}\text { Standardized } \\
\text { Coefficients }\end{array}$ & \multirow[t]{2}{*}{ T-value } & \multirow[t]{2}{*}{ T Table } & \multirow[t]{2}{*}{ Sig. } \\
\hline & $\mathrm{B}$ & Standard Error & Beta & & & \\
\hline Constant & -21.198 & 2.080 & & -10.203 & 1.645 & .000 \\
\hline $\mathrm{X} 1$ & .343 & .278 & .305 & 2.551 & & .000 \\
\hline $\mathrm{X} 2$ & 671 & .412 & .340 & 3.448 & & .016 \\
\hline $\mathrm{X} 3$ & .266 & .401 & .257 & 2.463 & & .010 \\
\hline $\mathrm{X} 4$ & .433 & .315 & .189 & 2.834 & & .022 \\
\hline$\times 5$ & .420 & .299 & .277 & 2.321 & & .001 \\
\hline \multicolumn{4}{|c|}{ Multiple Correlation (R) } & \multicolumn{3}{|l|}{0.681} \\
\hline \multicolumn{4}{|c|}{ Coef. Determinanant $\left(\mathrm{R}^{2}\right)$} & \multicolumn{3}{|l|}{0.464} \\
\hline \multicolumn{4}{|l|}{ Ftest } & \multicolumn{3}{|l|}{16.287} \\
\hline \multicolumn{4}{|l|}{ Ftable } & \multicolumn{3}{|l|}{2.400} \\
\hline \multicolumn{4}{|l|}{ Probability } & \multicolumn{3}{|l|}{0.000} \\
\hline
\end{tabular}




\section{Effect of Partial ( $t$ test):-}

The ability of dimensions of service that affects patient satisfaction partially is explained by the regression equation. Based on data on Table 1, a regression equation was prepared as: $\mathrm{Y}=-21198+0.343 \mathrm{X} 1+0.671 \mathrm{X} 2+0,266 \mathrm{X} 3+$ 0433 X5 X4 + $0.420+2.080$ and be explained as follows:

\section{Effect of Reliability:-}

Dimensions of reliability that had a positive impact on patient satisfaction at 0.343 meant if service quality dimension of reliability increased by 1 score it lead to increase patient satisfaction $34.3 \%$. Evaluation of the effect of reliability through $\mathrm{t}$-test showed $\mathrm{t}$-value $=2.551$ greater than $\mathrm{t}$-table $=1645$ (df: $50, \alpha: 5 \%)$ or $\mathrm{p}<.05$, proving that reliability influenced significantly quality of patient care.

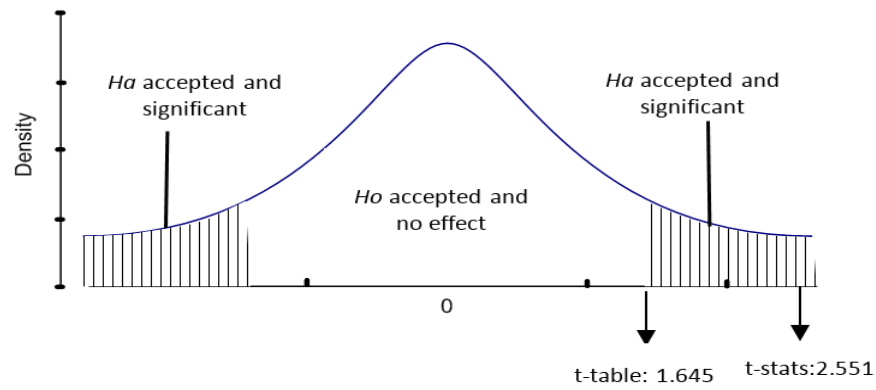

Figure 2:- Partial significance of Reliability

\section{Effect of Responsiveness:-}

Responsiveness dimension that had a positive impact on patient satisfaction $=.671$ meant if responsiveness increased 1 score it improved patient satisfaction $67.1 \%$. Evaluation of significance through showed t-value $=3,448$ bigger than t-table $=1645$ (df: $50, \alpha: 5 \%$ ) or $(p<.05)$. Evidently, responsiveness affected significantly quality of patient care.

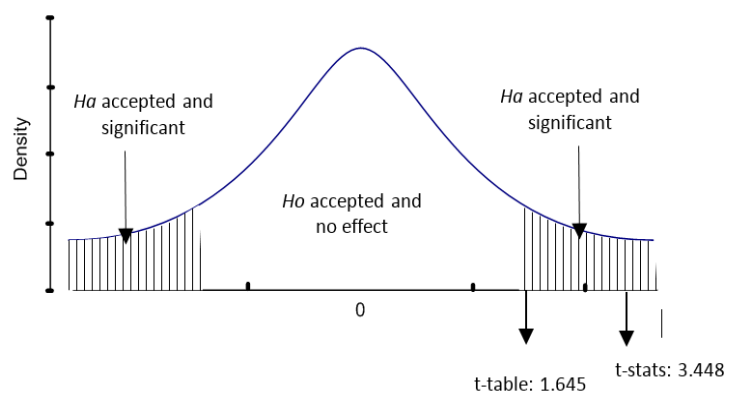

Figure 3:- Partial Significance of Responsiveness.

\section{Effect of Assurance:-}

Dimension of assurance that had a positive impact on patient satisfaction by 0,266 meant if assurance services increased 1 score it signified patient satisfaction 26.6\%. Evaluation of significance through $\mathrm{t}$-test showed $\mathrm{t}$-value $=$ 2463 , greater than t-table $=1645$ (df: $50, \alpha: 5 \%$ ) or $\mathrm{p}<.05$. Evidently, assurance affected significantly quality of patient care. 


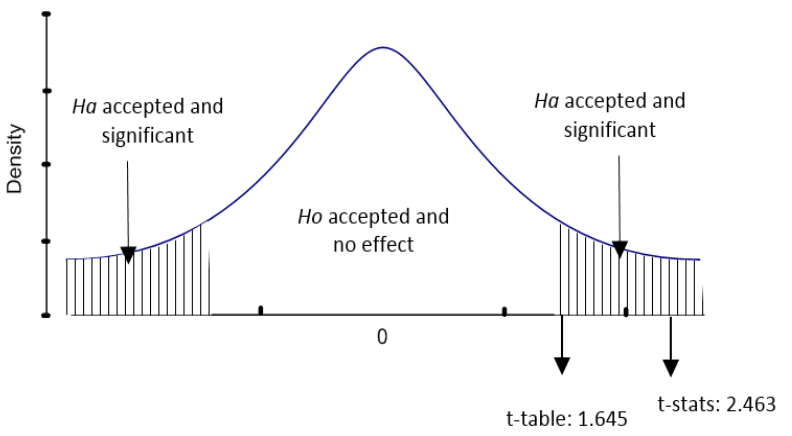

Effect of Empathy:-

Figure 4:- Partial Significance of Assurance

Empathy dimension that contributed a positive impact on patient satisfaction at 0.433 meant if an empathy increasedby 1 score, patient satisfaction increased $43.3 \%$. Evaluation of significance through t-test showed $\mathrm{t}$-value $=$ 2,834 , greater than t-table $=1645$ (df: $50, \alpha: 5 \%$ ) or $p=.002$. It is evident that emphaty affected significantly quality of patient care.

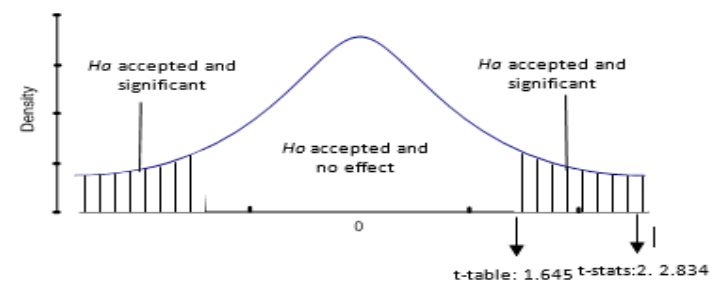

Figure 5:- Partial Significance of Empathy

\section{Effect of Tangible:-}

Tangible dimension that gave a positive impact on patient satisfaction at 0.420 meant if the tangible increased 1 score, patient satisfaction lead by $42 \%$. Evaluation of significance through $\mathrm{t}$-test $=2,321$ that was greater than $\mathrm{t}$-table $-1,645$ (df: $50, \alpha: 5 \%$ ) or $p=0001$ evidently proved that tangible affected significantly quality of patient care.

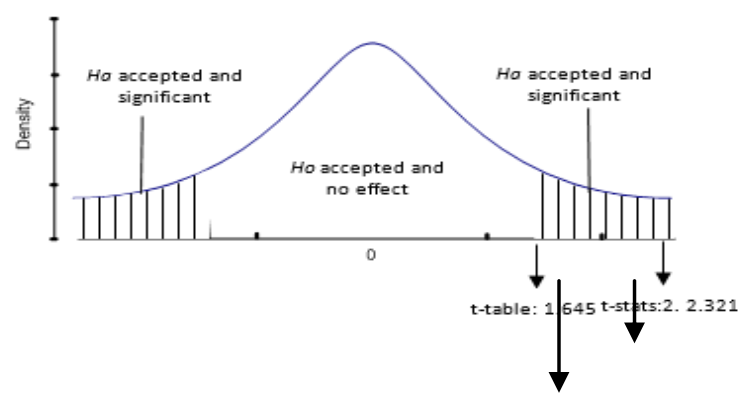

Figure 6:- Partial Significance of Tangible.

\section{Simultaneous Influence (Test F):-}

Simultaneous effect of dimensions of Reliability (X1), Responsiveness (X2), Assurance (X3), Empathy (X4) and Tangible (X5) on patient satisfaction (Y) was described by F-test. Data on Table 1 showed t-value $=16287$ and Ftable $=2.400$. If it was equal or exceeds the F-table, it was significant. The figure showed that F-value was greater than F-table; showing the null hypothesis (Ho) was rejected and the alternative hypothesis (Ha) was accepted. That is, the variable of reliability, responsiveness, assurance, empathy and tangible jointly affected significantly patient satisfaction in Dr Saiful Anwar Hospital Malang ( $\mathrm{p}=0.000)$. 


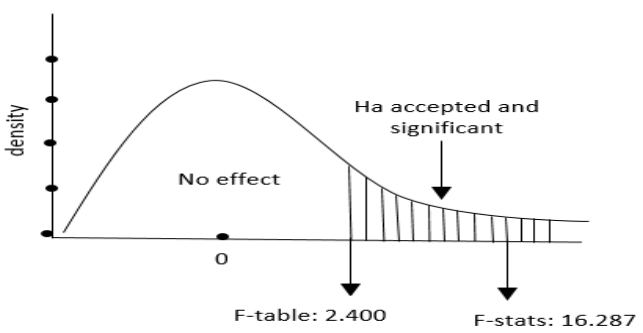

Beta Test:-

Figure 7:- Determinant Coefficient Significance

Beta test was to examine independent variables that had the most dominant effect on dependent variable, the variable that had the highest regression coefficient. Result of analysis as seen in Table 1 was that among service dimension variables, i.e. Reliability (X1), Responsiveness (X2), Assurance (X3), Empathy (X4) and Tangible (X5) to client satisfaction (Y), Responsiveness (X2) gained the highest value of standardized beta coeffisien $=3,448$. Thus, responsiveness was a service variable that had the most dominant influence on patient satisfaction in Dr. Saiful Anwar Hospital in Malang.

\section{Determinants $\left(\mathbf{R}^{2}\right)$ Test:-}

Determinant test was used to determine the amount of free variable to variable terminated bound. Table 1 showed coefficient of determination $\left(\mathrm{R}^{2}\right)=.464$. This meant all variables of quality service dimension covering reliability, responsiveness, assurance, empathy, tangible contributed patient satisfaction in Dr. Saiful Anwar Hospital Malang up to $46.40 \%$. The remaining $54.60 \%$ was influenced by other variables not analyzed in this study.

\section{Conclusion:-}

1. Analysis of overall service gap dimension, the fit between services provided by Dr. Saiful Anwar Hospital in Malang with patient expectations shows there is a gap or level of satisfaction at (-10.54). This score was categorized as moderate; yet it fully meets expectations of patients, the services provided is quite good.

2. 2). The variables of service quality dimensions (Reliability, Responsiveness, Assurance, Empathy, Tangible) jointly have positive effect and significant impact on patient satisfaction of Dr Saiful Anwar Hospital Malang. F-value (16.287) is greater than F-table (2.640)

3. The variables of service quality dimensions (Reliability, Responsiveness, Assurance, Empathy, Tangible) partially have positive influence and significant impact on patient satisfaction of Dr Saiful Anwar Hospital Malang. This is supported by the t-value of each variable is greater than t table (1.645). The $t$-values of each of these variables are: Assurance (2463), Reliability (2551), Tangible (2321), Responsiveness (3448), Empathy (2834). Furthermore, the value of $\mathrm{R}^{2}=(0464)$ showed that $46.4 \%$ variable of customer satisfaction is contributed by the service quality that is Reliability, Responsiveness, Assurance, Empathy, and Tangible. Other remaining $53.6 \%$ is contributed by other variables that are not included in this research model

4. Results of Beta Test shows that responsiveness variable achieves regression coefficient $=.671$; that means responsiveness has a dominan influence on the patient satisfaction of Dr. Saiful Anwar Hospital Malang.

\section{References:-}

1. Ahmad S, (1997). Dimensi Sosial dalam Pelayanan Kesehatan, Jakarta: PT. Bina Rupa Aksara.

2. Azwar A, (1996). Menjaga Mutu Pelayanan Kesehatan. Jakarta: Penerbit Pustaka Sinar Harapan.

3. Assauri (2003), Manajemen PemasaranJasa, Jilid1. Jakarta: PT Gramedia

4. Denhardt, Janer V, and Robert B. Denhardt. (2003). The New Public Service: Serving Not Steering. Armonk, N.Y: M. E. Sharpe.

5. Fandy, Tjiptono dan Gregorius Chandra. (2005). Service, Quality Satisfaction. Yogyakarta: Andi Offset.

6. Kotler, Philip. (2003). Manajemen Pemasaran. Edisi Kesebelas, Jakarta: Indeks Kelompok Gramedia

7. Loveock, Christoper, (1988), Managing Service: Marketing, Operations and Human Resources, London: Prentice Hall Inc.

8. Novianti, R.. Artanti., (2015). Pengaruh Kualitas Pelayanan Terhadap Word of Mouth (WOM) Melalui Kepuasan Sebagai Variabel Intervening. Jurnal Ilmu Manajemen, 1(1):21-32.

9. Parasuraman A, Zeithaml, Valerie A, Berry, Leonard L (1985), "A Conceptual Model of Service Quality and its Implications for Future Research, ”.Journal of Marketing, 49(2): 210-220. 
10. Parasuraman, A, Valerie A. Zeithaml, Leonard L. Berry. (1998). SERVQUAL: A Multiple Item Scale for Measuring Consumer Perception of Service Quality. Journal of Marketing, 64(1): 12-37.

11. Schnaars, Steven P., (1991). Marketing Strategy: A Customer Driven Approach. 2nd ed. The Free Press. New York

12. Yamit, Zulian. (2005). Manajemen Kualitas Produk dan Jasa. Edisi Pertama, Cetakan Keempat, Penerbit Ekonisia, Kampus Fakultas Ekonomi UII Yogyakarta.

13. Yazid. (1999). Pemasaran Jasa, Konsep dan Implementasi. Yogyakarta: Fakultas Ekonomi UII.

14. Zeithami, Valerie A, (1988), "Consumer Perceptions of Price, Quality and Value: A Means End Model and Synthesis of Evidence, ”Journal of Marketing, 52(2):250-262.

15. Zeithaml, et.al. (1990). Delivering Quality Service. New York: Free Press. 